Article

\title{
Genome Analysis of Acinetobacter lwoffii Strains Isolated from Permafrost Soils Aged from 15 Thousand to 1.8 Million Years Revealed Their Close Relationships with Present-Day Environmental and Clinical Isolates
}

\author{
Andrey L. Rakitin ${ }^{1}$, Alexandra Y. Ermakova ${ }^{1}$, Alexey V. Beletsky ${ }^{1}$, Mayya Petrova ${ }^{2} \mathbb{D}$, Andrey V. Mardanov ${ }^{1}(\mathbb{D}$ \\ and Nikolai V. Ravin ${ }^{1, *}$ \\ 1 Research Center of Biotechnology of the Russian Academy of Sciences, Institute of Bioengineering, \\ 119071 Moscow, Russia; rakitin@biengi.ac.ru (A.L.R.); alex.ermakova@mail.ru (A.Y.E.); \\ mortu@yandex.ru (A.V.B.); mardanov@biengi.ac.ru (A.V.M.) \\ 2 Institute of Molecular Genetics of National Research Centre "Kurchatov Institute", 123098 Moscow, Russia; \\ petrova@img.ras.ru \\ * Correspondence: nravin@biengi.ac.ru
}

Citation: Rakitin, A.L.; Ermakova A.Y.; Beletsky, A.V.; Petrova, M.; Mardanov, A.V.; Ravin, N.V. Genome Analysis of Acinetobacter lwoffii Strains Isolated from Permafrost Soils Aged from 15 Thousand to 1.8 Million Years Revealed Their Close Relationships with Present-Day Environmental and Clinical Isolates. Biology 2021, 10, 871. https://doi.org/10.3390/biology 10090871

\section{Academic Editors:}

Chrissoula Voidarou, Athina S. Tzora and Georgios Rozos

Received: 27 July 2021

Accepted: 1 September 2021

Published: 4 September 2021

Publisher's Note: MDPI stays neutral with regard to jurisdictional claims in published maps and institutional affiliations.

Copyright: (c) 2021 by the authors. Licensee MDPI, Basel, Switzerland. This article is an open access article distributed under the terms and conditions of the Creative Commons Attribution (CC BY) license (https:// creativecommons.org/licenses/by/ $4.0 /)$.
Simple Summary: Arctic ecosystems are an extreme habitat characterized by a negative average annual temperature and the presence of permafrost that occupies about $25 \%$ of the land. Permafrost can retain viable microorganisms for several million years and therefore it is a source of unique "ancient" microbes. Acinetobacter lwoffii are aerobic chemoorganotrophic bacteria widespread in a variety of natural and artificial environments, and have been reported as hospital pathogens associated with nosocomial infections. Here, we carried out a genome-wide analysis of five strains of A. lwoffii isolated from permafrost aged from 15 thousand to 1.8 million years. Surprisingly, we did not reveal genetic determinants that distinguish them from modern clinical and environmental $A$. lwoffii isolates. On the phylogenetic tree permafrost strains do not form a separate cluster, but are related to various clinical isolates. The genomes of clinical and permafrost strains contain similar mobile elements and prophages, which indicates an intense horizontal gene transfer. Like clinical isolates, permafrost strains harbored antibiotic resistance genes, although plasmids from the modern strains are enriched with antibiotic resistance genes compared to permafrost ones. The obtained results indicate that thawing of permafrost caused by global warming could release new potentially pathogenic strains of Acinetobacter into the modern biosphere.

Abstract: Microbial life can be supported at subzero temperatures in permafrost up to several million years old. Genome analysis of strains isolated from permafrost provides a unique opportunity to study microorganisms that have not previously come into contact with the human population. Acinetobacter lwoffii is a typical soil bacterium that has been increasingly reported as hospital pathogens associated with bacteremia. In order to identify the specific genetic characteristics of ancient permafrost-conserved strains of $A$. lwoffii and their differences from present-day clinical isolates, we carried out a genome-wide analysis of five strains of $A$. lwoffii isolated from permafrost aged from 15 thousand to 1.8 million years. Surprisingly, we did not identify chromosomal genetic determinants that distinguish permafrost strains from clinical $A$. lwoffii isolates and strains from other natural habitats. Phylogenetic analysis based on whole genome sequences showed that permafrost strains do not form a separate cluster and some of them are most closely related to clinical isolates. The genomes of clinical and permafrost strains contain similar mobile elements and prophages, which indicates an intense horizontal transfer of genetic material. Comparison of plasmids of modern and permafrost strains showed that plasmids from the modern strains are enriched with antibiotic resistance genes, while the content of genes for resistance to heavy metals and arsenic is nearly the same. The thawing of permafrost caused by global warming could release new potentially pathogenic strains of Acinetobacter. 
Keywords: Acinetobacter lwoffii; permafrost; genome; evolution; antibiotics resistance; plasmid; horizontal gene transfer

\section{Introduction}

Arctic ecosystems are an extreme habitat characterized by a negative average annual temperature and the presence of permafrost soils. Permafrost is the part of the Earth's upper crust that does not thaw when temperatures rise seasonally. Permafrost occupies about $25 \%$ of the land [1]. Russia ranks first in the world in terms of permafrost area, which makes up about $65 \%$ of its territory [2]. Permafrost soils contain a wide range of microorganisms including bacteria, archaea, algae, and fungi [3-7]. Permafrost can retain viable microorganisms under stable conditions at low temperatures for several million years $[7,8]$ and therefore it is a source of unique "ancient" microorganisms.

Antibiotic resistance is a major global health problem that threatens to negate the benefits of the discovery of antibiotics [9]. Although genes for antibiotic resistance are common in natural microbial populations, a number of questions related to the role of human activity in the wide distribution of diverse determinants of resistance in pathogenic bacteria remain open $[10,11]$. In this regard, the search for antibiotic resistance genes in microorganisms that have not previously come into contact with the human population is of great interest [12]. Many studies on permafrost have reported the presence of genes coding for resistance to several classes of antibiotics [13-18] and heavy metals $[19,20]$ similar to ones observed in present day clinical and environmental strains. The Psychrobacter maritimus strain, resistant to tetracycline and streptomycin, was isolated from 15,000-35,000 years old permafrost sediments sampled from the coast of the East Siberian Sea. The genes conferring resistance to streptomycin ( $\operatorname{str} A-\operatorname{str} B)$ and tetracycline (tet $R$-tet $H)$ were localized on the plasmid pKLH80 [13]. As a result of the analysis of the genome of Staphylococcus hominis MMP2, isolated from 3.5 million years old permafrost soils in the Lena River area, genes encoding resistance to aminoglycosides, beta-lactams, macrolides and chloramphenicol were identified [8]. Perron et al. used functional metagenomics to retrieve antibiotic resistance genes from bacteria isolated from Canadian high Arctic permafrost and identified genes conferring clinical levels of resistance against aminoglycoside, $\beta$-lactam and tetracycline antibiotics [17]. Twenty eight bacterial species were cultured form a Siberian permafrost sample dated at 2.7 million years and resistance to antibiotics was phenotypically detected in all 10 Gram-negative species [18]. No significant differences in antibiotic resistance profiles between modern and ancient isolates of each species were found [18]. Direct evidence for the presence of antibiotic resistance genes in the permafrost microbiome has been obtained as a result of metagenomic analyses of 30,000-year-old permafrost sediments in Alaska [15]. This study revealed a highly diverse genes encoding resistance to $\beta$-lactam, tetracycline and glycopeptide antibiotics [15].

Bacteria of the genus Acinetobacter, Gram-negative cocci, belong to the family Moraxellaceae, order Pseudomonadales, class $\gamma$-Proteobacteria. Acinetobacter species are aerobic chemoorganotrophic saprophytes; they do not form spores, are not able to ferment glucose and carbohydrates. Acinetobacter sp. are widespread in various ecological niches [21-23]. $A$. lwoffii strains occur in a variety of natural and artificial environments such as forest and agricultural soils, animal and human skin and gut, fresh and seawater [24]. While $A$. baumannii is the most clinically important Acinetobacter species causing infections, A. lwoffii have been increasingly reported as hospital pathogens associated with nosocomial infections like septicemia, pneumonia, meningitis, urinary tract infections, skin, gastroenteritis and wound infections [25-27].

Acinetobacter sp. have a fairly variable genome that contains various mobile genetic elements, such as IS elements, transposons, plasmids and bacteriophages, which are often associated with antibiotic resistance [28-30]. Until now, most studies on sequencing and genome analysis have been devoted to A. lwoffii strains isolated from clinical material. Only 
a few genomes of $A$. lwoffii strains isolated from natural environments have been reported, namely A. lwoffii ZS207 from a microbial mat in a gold mine [31], A. lwoffii M2a from a honey sample but probably originated from bee intestines [32], and A. lwoffii GC2 from petroleum-contaminated soil [33,34].

In order to identify the specific genetic characteristics of ancient permafrost-conserved strains of $A$. lwoffii and their differences from present-day clinical isolates, we carried out a genome-wide analysis of five strains of $A$. lwoffii isolated from permafrost aged from 15 thousand to 1.8 million years. Surprisingly, we did not reveal chromosomal genetic determinants that distinguish permafrost strains from clinical strains and strains from other non-clinical environments.

\section{Materials and Methods}

\subsection{Strains of A. lwoffii}

The objects of the study were five strains of $A$. lwoffii isolated from samples of permafrost sediments collected in the Kolyma lowland region, the Republic of Yakutia, Russia [35]. We herein referred to these strains as "permafrost" strains, which never come into contact with clinical isolates. It was previously shown that most of the studied strains are resistant to antibiotics and heavy metals [20,35], as summarized in Table 1.

Table 1. Analyzed permafrost strains of A. lwoffii.

\begin{tabular}{ccccc}
\hline Strain & Isolation Depth (m) & $\begin{array}{c}\text { Age of Permafrost } \\
\text { (Thousand Years) }\end{array}$ & Resistance to Antibiotics & Resistance to Heavy Metals \\
\hline ED23-35 & 4.5 & $20-40$ & $\mathrm{Sm}, \mathrm{Sp}$ & $\mathrm{Hg}, \mathrm{Cr}, \mathrm{Co}, \mathrm{Cd}, \mathrm{Zn}, \mathrm{Ni}$ \\
ED45-23 & 2.9 & $20-40$ & - & $\mathrm{Hg}, \mathrm{As}, \mathrm{Cu}$ \\
ED9-5A & 6.5 & $15-30$ & - & $\mathrm{Hg}, \mathrm{As}, \mathrm{Cr}, \mathrm{Cd}, \mathrm{Zn}, \mathrm{Cu}$ \\
VS15 & 34.0 & $20-40$ & $\mathrm{Amp}, \mathrm{Cm}, \mathrm{Sm}, \mathrm{Sp}$ & $\mathrm{Co}, \mathrm{Cd}, \mathrm{Zn}, \mathrm{Cu}$ \\
EK30A & 47.9 & $1600-1800$ & $\mathrm{Amp}, \mathrm{Sm}, \mathrm{Sp}$ & $\mathrm{Cr}, \mathrm{Co}, \mathrm{Cd}, \mathrm{Cu}$ \\
\hline
\end{tabular}

All strains were grown in lysogeny broth (LB) medium or solidified LB medium (LA) at $30^{\circ} \mathrm{C}$. When required, antibiotics were added at the following final concentrations ( $\mu \mathrm{g} \mathrm{mL}^{-1}$ ): streptomycin $(\mathrm{Sm})$ 100, spectinomycin (Sp) 100-200, chloramphenicol (Cm) 20, and ampicillin (Amp) 100.

\subsection{Genome Sequencing and Assembly}

A single colony of the A. lwoffii strain was inoculated with $5 \mathrm{~mL}$ of LB medium and grown with shaking at $30^{\circ} \mathrm{C}$ for $16-20 \mathrm{~h}$. Cells were harvested by centrifugation $(10,000 \times g$ for $5 \mathrm{~min}$ ), and total DNA was isolated using a DNeasy PowerSoil Kit (Qiagen).

Genomic DNA was sequenced using Illumina and Oxford Nanopore platforms. The shotgun genome library was prepared using the NEBNext Ultra II DNA library prep kit (New England BioLabs, Ipswich, MA, USA). The obtained libraries were sequenced on Illumina MiSeq (Illumina, San Diego, CA) using MiSeq Reagent Kit v3 (600-cycle) in a paired reads $(2 \times 300 \mathrm{nt})$ mode (Supplementary Table S1). Adapter removal and trimming of low-quality sequences $(\mathrm{Q}<30)$ were performed using Cutadapt v.1.8.3 [36] and Sickle v.1.33 (https:/ / github.com/najoshi/sickle, accessed on 27 July 2021), respectively. Trimmed reads were merged using FLASH v.1.2.11 [37].

Genomic DNA was additionally sequenced on a MinION system (Oxford Nanopore, UK) using the 1D Genomic DNA by ligation protocol and kit (SQK-LSK108). The libraries were sequenced in an R9.4 flow cell (FLO-MIN106) using MinION device (Supplementary Table S1).

The resulting Illumina and Nanopore reads were de novo assembled into contigs using hybrid assembler Unicycler v. 0.4.8 [38]. 


\subsection{Annotation and Analysis of the Genomes}

Gene search and annotation of obtained genomes were performed using the RAST server 2.0 [39].

The core genome of $A$. lwoffii strains was determined by clustering all genes selected by the BLASTclust program from the BLAST package [40]. Genes whose predicted protein products had more than $50 \%$ amino acid sequence identity across more than $80 \%$ of the length were combined into one cluster. Clusters containing at least one protein from each genome formed the core genome.

For genome-based phylogenetic analysis, 1585 single copy genes present in each genome (14 strains of $A$. lwoffi and A. pseudolwoffii CIP 64.10) were identified by clustering of all genes at $70 \%$ nucleotide sequence identity threshold, using the Blastclust program of the NCBI BLAST package. For each single copy gene multiple alignment was build using MAFFT program [41]. The obtained alignments were concatenated, and the poorly aligned regions were removed using Gblocks [42]. Based on the obtained alignment, a maximum likelihood tree was built using the PhyML [43] with default parameters (HKY85 nucleotide substitution model was used, equilibrium base frequencies were estimated by counting the occurrence of bases in the alignment, gamma distribution with estimated shape parameter was used to model 4 substitution rate categories, no invariant sites, branch support values were calculated using the approximate Bayes method).

The average nucleotide identity (ANI) between the genomes was calculated using the ani.rb script from the Enveomics Collection [44].

The copy numbers of plasmids relative to the chromosome was deduced from the average sequencing depths of the corresponding contigs calculated by Unicycler v. 0.4.8.

The Comprehensive Antibiotic Resistance Database (CARD) [45] was used to search for antibiotic resistance genes. The ISfinder server [46] was used to search for insertion sequences. The search for prophages was performed using the PHASTER program [47], followed by verification of the results by searches against NCBI databases. To identify composite transposons, we searched for pairs of IS elements (nucleotide sequence identity above $99 \%$ ) located at a distance of up to $15 \mathrm{~kb}$ in the same orientation.

A concatenated amino acid sequence of eight proteins (UreABCDEFGJ) was used to construct a phylogenetic tree for the urease operon. The sequences were aligned using the MUSCLE algorithm in the MEGA package [48]; the phylogenetic tree was constructed using the maximum likelihood method [49].

\subsection{Determination of the Ability of A. lwoffii Strains to Degrade Urea}

For the analysis, a plate test on Christensen medium was used [50]. A single colony was inoculated into $5 \mathrm{~mL}$ of LB and grown overnight at $30^{\circ} \mathrm{C}$. An aliquot was taken, inoculated into $5 \mathrm{~mL}$ of Christensen medium with glucose and urea, and grown overnight. The $\mathrm{OD}_{600}$ of the culture was adjusted 0.15 . Then, $3 \mu \mathrm{L}$ of the resulting culture was dropped onto a Christensen Urea Agar plate. The cultures were grown for $24 \mathrm{~h}$ at $30^{\circ} \mathrm{C}$. Increase in $\mathrm{pH}$ due to the production of ammonia from urea hydrolysis results in a color change from yellow (pH 6.8) to bright pink ( $\mathrm{pH} 8.2$ ).

\section{Results and Discussion}

\subsection{General Genome Characteristics}

The genomes of A. lwoffii strains ED23-35, ED45-23, ED9-5A, VS15 and EK30A were sequenced using a combination of Illumina and Nanopore technique. Following hybrid de novo assembly using the Unicycler assembly pipeline, a complete circular chromosome sequence and a set of contigs representing plasmids were obtained for each strain. The size of the chromosomes of the sequenced strains varied from 3.16 to $3.26 \mathrm{Mbp}$, the number of plasmids was from 6 to 15 (Table 2). 
Table 2. Genomes of permafrost strains of $A$. lwoffii.

\begin{tabular}{|c|c|c|c|c|}
\hline \multirow{2}{*}{ Strain } & \multirow{2}{*}{$\begin{array}{c}\text { Chromosome } \\
\text { Size (bp) }\end{array}$} & \multicolumn{3}{|c|}{ Plasmids } \\
\hline & & Name & Size (bp) & Resistance Genes $^{1}$ \\
\hline \multirow[t]{7}{*}{ ED23-35 } & $3,160,760$ & pALWED 1.1 & 287,861 & tet $(H)$, mer, chr, czc, nreB \\
\hline & & pALWED 1.2 & 48,955 & \\
\hline & & pALWED 1.3 & 16,067 & $c h r$ \\
\hline & & pALWED 1.4 & 14,116 & \\
\hline & & pALWED 1.5 & 6715 & \\
\hline & & pALWED 1.7 & 4861 & \\
\hline & & pALWED 1.8 & 4135 & aad $A 27$ \\
\hline \multirow[t]{9}{*}{ ED45-23 } & $3,260,192$ & pALWED 2.1 & 196,557 & mer, ars, cop \\
\hline & & pALWED 2.2 & 43,270 & \\
\hline & & pALWED 2.3 & 22,769 & \\
\hline & & pALWED 2.4 & 11,092 & \\
\hline & & pALWED 2.5 & 10,584 & \\
\hline & & pALWED 2.6 & 9201 & \\
\hline & & pALWED 2.7 & 8816 & \\
\hline & & pALWED 2.8 & 8120 & \\
\hline & & pALWED 2.9 & 6308 & \\
\hline \multirow[t]{6}{*}{ ED9-5A } & $3,231,133$ & pALWED 3.6 & 185,756 & mer, ars, cop, czc \\
\hline & & pALWED 3.1 & 138,030 & \\
\hline & & pALWED 3.5 & 16,567 & $\operatorname{chr}$ \\
\hline & & pALWED 3.2 & 15,656 & \\
\hline & & pALWED 3.7 & 9958 & \\
\hline & & pALWED 3.3 & 8055 & \\
\hline \multirow[t]{6}{*}{ VS15 } & $3,260,140$ & pALWVS 1.1 & 134,096 & $c o p, c z c$ \\
\hline & & pALWVS 1.2 & 15,780 & \\
\hline & & pALWVS 1.4 & 11,964 & \\
\hline & & pALWVS 1.3 & 10,985 & \\
\hline & & pALWVS 1.5 & 4677 & \\
\hline & & pALWED 1.8 & 4135 & aadA27 \\
\hline \multirow[t]{15}{*}{ EK30A } & $3,183,510$ & pALWEK 1.1 & 209,982 & \\
\hline & & pALWEK 1.2 & 12,172 & \\
\hline & & pALWEK 1.12 & 11,382 & \\
\hline & & pALWEK 1.3 & 10,347 & \\
\hline & & pALWEK 1.10 & 9202 & \\
\hline & & pALWEK 1.13 & 8910 & \\
\hline & & pALWEK 1.4 & 8635 & cflA \\
\hline & & pALWEK 1.5 & 8227 & chr \\
\hline & & pALWEK 1.7 & 6691 & \\
\hline & & pALWEK 1.8 & 5324 & \\
\hline & & pALWEK 1.14 & 4760 & \\
\hline & & pALWEK 1.15 & 4677 & \\
\hline & & pALWED 1.8 & 4135 & $\operatorname{aad} A 27$ \\
\hline & & pALWEK 1.17 & 4130 & \\
\hline & & pALWEK 1.16 & 2621 & \\
\hline
\end{tabular}

${ }^{1}$ The tet $R(H)$ gene confers resistance to tetracycline, $c f l A$ - to chloramphenicol/fluorochloramphenicol, aad $A 27$ - to streptomycin/spectinomycin, $n r e B-$ to $\mathrm{Ni}, c z c$ - to $\mathrm{Co} / \mathrm{Zn} / \mathrm{Cd}$, cop - to $\mathrm{Cu}$, chr-to $\mathrm{Cr}$, ars - to As, mer-to $\mathrm{Hg}$.

All contigs were assembled as circular molecules and thus represented the complete chromosome and plasmid sequences. All plasmids, previously reported in strains ED2335, ED45-23 and VS15, were identified in the assemblies with the exception of plasmids pALWED 1.6 (strain ED23-35) and pALWED 3.4 (strain ED9-5A), whose sequences were found in the chromosomes of the corresponding strains. In the EK30A strain plasmids pALWEK 1.6, pALWEK 1.9 and pALWEK 1.11 were not found, but one previously unreported plasmid, designated pALWEK 1.17 (4130 bp long), was discovered. One plasmid, pALWED 1.8, was found in strains ED23-35, VS15 and EK30A, while other plasmids occurred in one strain only. 
The ANI values between all permafrost strains, as well as between permafrost and nine other strains of $A$. lwoffii were above the 95\% threshold for species delineation [51,52], indicating that all of them belong to the same species (Supplementary Table S2).

Annotation of the genome sequences predicted from 3387 to 3547 protein-coding genes, among which about $70 \%$ were functionally annotated. Each genome contained 7 copies of 5S rRNA, 16S rRNA and 23S rRNA, and from 83 to 87 tRNA genes (Table 3).

Table 3. General characteristics of the genomes.

\begin{tabular}{cccccc}
\hline \multirow{2}{*}{ Parameter } & \multicolumn{5}{c}{ Strain } \\
\cline { 2 - 6 } & ED23-35 & ED45-23 & ED9-5A & VS15 & EK30A \\
\hline Predicted genes & 3560 & 3644 & 3653 & 3496 & 3495 \\
Protein-coding genes & 3453 & 3537 & 3547 & 3392 & 3387 \\
Protein-coding genes with & 2362 & 2463 & 2543 & 2404 & 2405 \\
predicted function & $(68,4 \%)$ & $(69.6 \%)$ & $(71.7 \%)$ & $(70.9 \%)$ & $(71.0 \%)$ \\
tRNA genes & 86 & 86 & 85 & 83 & 87 \\
G+ C content (chromosome) & 43.22 & 43.20 & 43.21 & 43.26 & 43.01 \\
\hline
\end{tabular}

3.2. Core Genomes and Phylogenetic Relationships of Environmental and Clinical Strains of A. lwoffii

For the pangenome analysis, we used nine genomes of $A$. lwoffii deposited in the GenBank database and five genomes of permafrost strains sequenced in this work. Genomes of A. lwoffii strains ZS207, M2a, GC2 and five permafrost strains were combined into the "environmental" group, six genomes of clinical $A$. lwoffii strains were allocated into the "clinical" group (Table 4). The core genome of environmental and clinical groups comprised 2224 and 2266 genes, respectively. The core genome of all 14 strains of $A$. lwoffii consisted of 2096 genes.

Table 4. Core genomes of clinical and environmental strains of $A$. lwoffii.

\begin{tabular}{cccc}
\hline Strain & Source & Protein-Coding Genes & $\begin{array}{c}\text { Genes in the } \\
\text { Core Genome }\end{array}$ \\
\hline ED23-35 & Environmental group & 2224 \\
ED45-23 & Permafrost & 3453 & \\
ED9-5A & Permafrost & 3537 & \\
VS15 & Permafrost & 3547 & \\
EK30A & Permafrost & 3392 & \\
ZS207 & Permafrost & 3387 & \\
M2a & Gold mine & 3230 & \\
GC2 & Honey & 3533 & \\
\hline \multicolumn{4}{c}{ Petroleum-contaminated soil } \\
SH145 & Clinical group & 3267 & \\
NIPH 715 & Skin & 3134 & \\
CIP 70.31 & Pus & 3314 & \\
NIPH 478 & Gangrenous lesion & 3503 & \\
NIPH 512 & Ear swab & 3088 & \\
TG19636 & Unknown & 3237 & \\
\hline
\end{tabular}

The core genome of environmental strains exceeds the total core genome by only 128 genes (Supplementary Table S3). Most of these genes were absent in only one (101 genes) or two (19 genes) out of 6 clinical strains; only one gene was present in all environmental isolates and absent in all analyzed clinical strains. It encodes a TauE/SafE family sulfite exporter. TauE/SafE proteins are involved in the transport of anions across the cytoplasmic membrane and were found to act as sulfite/organosulfonate exporters in the metabolism of C2 sulfonates [53]. In all permafrost strains two copies of these genes are located on the 
chromosomes and in strain ED45-23 an additional copy was found on plasmid pALWED2.1. Organosulfonates are widespread in nature, particularly in the humic material of soil [54], and probably could be utilized by permafrost strains.

A similar picture was observed when comparing the core genome of clinical strains with the core genome of all strains (Supplementary Table S4). We found 170 genes common to all clinical strains were absent in one or several (maximum five out of eight) environmental strains. The real number of differences between the core genomes of environmental and clinical strains is probably even smaller, since the observed differences are primarily associated with the quality of the genome assembly. For example, the complete genome of strain ED9-5A lacked only six genes present in all clinical isolates, while 62 genes were not identified in the draft genome of strain GC2, assembled into 285 contigs.

However, the absence of three genetic loci in environmental isolates should be noted. Two environmental strains, ZS207 and ED23-35, lacked genes encoding the copper resistance proteins CopC and CopD, while strains GC2 and ED23-35 lacked the complete biotin biosynthesis operon. Four permafrost strains lack the gene encoding competence protein ComEA involved in uptake of exogenous DNA [55]. Perhaps these functions are more in demand in the clinical environment. Particularly, natural competence is common among clinical isolates of Acinetobacter spp., and is an important trait for acquisition of antibiotic resistance [56]. Copper resistance may play a role in survival in the human host or hospital environment and is important for full virulence of A. baumannii [57].

Concatenated nucleotide sequences of 1585 single copy genes were used for phylogenetic analysis of 14 strains of $A$. lwoffii. The structure of the resulting tree showed that environmental and clinical strains do not form separate clusters (Figure 1). Moreover, five strains isolated from permafrost soils do not form a separate branch, and one of them, EK30A, clustered with the clinical strain SH145, with which it also has the highest ANI value. Only two permafrost strains, VS15 and ED23-35, turned out to be very close on the phylogenetic tree, and they also had the highest ANI of $97.64 \%$.

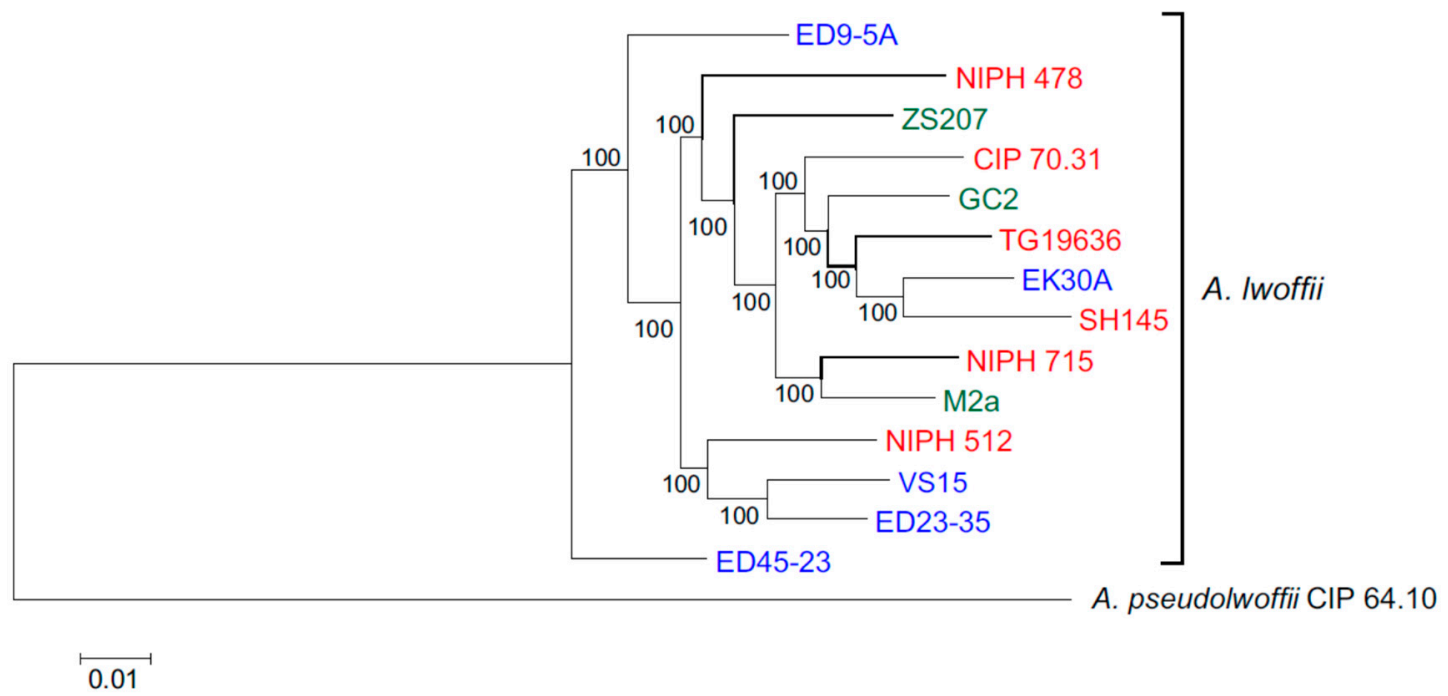

Figure 1. Genome-based phylogeny of A. lwoffii. The maximum likelihood tree is based on concatenated nucleotide sequences of 1585 single copy genes. Clinical, permafrost and other natural isolates of $A$. lwoffii are shown in red, blue and green, respectively. A. pseudolwoffii CIP 64.10 was used to root the tree.

\subsection{Antibiotics Resistance Genes}

As a result of a comparative analysis of the genomes of clinical and environmental strains of $A$. lwoffii, potential genes for antibiotic resistance that are common and unique for each group were identified (Table 5). All clinical and environmental strains contain genes encoding the carbapenem-hydrolyzing class D $\beta$-lactamase (bla $\left.a_{O X A-134}\right)$, chloramphenicol acetyltransferase (cat), and $\mathrm{ABC}$ family transport proteins MacAB-TolC. The bla OXA-134 
gene is widespread in A. lwoffii and has been proposed as a tool for rapid identification of this species [58]. All these common resistance genes are localized on the chromosomes.

Table 5. Antibiotics resistance genes in the A. lwoffii genomes.

\begin{tabular}{cccc}
\hline \multirow{2}{*}{ Gene } & Protein & \multicolumn{2}{c}{ Strain Group } \\
\cline { 3 - 4 } & Chinical (6) & Environmental (8) \\
\hline cat & Chloramphenicol acetyltransferase & 6 & 8 \\
bla $O X A-134$ & OXA-134 family class D $\beta$-lactamase & 6 & 8 \\
macAB, tolC & Drug efflux ABC-type transporter & 6 & 8 \\
sul2 & Dihydropteroate synthase & $3^{1}$ & 0 \\
aph $\left(3^{\prime \prime}\right)-\mathrm{Ib}$ & Aminoglycoside 3'-phosphotransferase & $1^{2}$ & 0 \\
aph $(6)-\mathrm{I}$ & Aminoglycoside-6-phosphotransferase & $1^{2}$ & 0 \\
aadA27 & Streptomycin- spectinomycin & 0 & 3 \\
tet $(H)$ & 3"-adenylyltransferase & 0 & 1 \\
cflA & Tetracycline efflux MSF transporter & 0 & 1 \\
\hline
\end{tabular}

1 sul2 was found in strains NIPH 478, NIPH 715, TG19636; ${ }^{2}$ Genes $\operatorname{aph}(3$ ")-Ib and $\operatorname{aph}(6)-\mathrm{I}$ were found in strain TG19636.

Strains ED23-35, VS15, and EK30A are resistant to streptomycin and spectinomycin [35], which is determined by the aadA27 gene located on the plasmid pALWED1.8 [16]. The VS15 strain is resistant to chloramphenicol [35] due to the presence of the cflA gene on the plasmid pALWVS1.4 [59]. The experimentally shown weak resistance of strain ED23-35 to tetracycline is probably determined by plasmid pALWED1.1 (GenBank KX426227) carrying the $\operatorname{tet}(H)$ gene (our unpublished data). Genes aph(3")-Ib and aph(6)-I found in the strain TG19636 are also located on a plasmid.

Thus, it can be assumed that antibiotic resistance genes specific for individual strains are localized on plasmids that can facilitate their horizontal transfer. At the same time, genes of chloramphenicol acetyltransferase, $\beta$-lactamase, and MacAB-TolC efflux transporters common for clinical and environmental strains are located on the chromosome and have been vertically inherited.

\subsection{Mobile Elements}

Insertion sequences play an important role in the evolution of the host genome and are involved in mutagenesis and gene activation, as well as in the rearrangement of chromosomes and plasmids [60]. IS elements are typically small (700-2500 bp) self-transferable genetic elements that contain usually one open reading frame flanked by inverted repeats and encoding a transposase that catalyzes DNA cleavage and transfer of the IS element [61].

The ISfinder database [46] contains 135 IS elements that were found in the genomes of various Acinetobacter species. IS elements in the genomes of permafrost strains of $A$. lwoffii were identified by searches against the ISfinder database [46]. For further analysis, only intact IS elements exhibiting more than $95 \%$ nucleotide sequence identity with the IS elements deposited in the database, were retained.

As a result, it was found that the genomes of permafrost strains contained from 70 to 133 copies of IS elements (Table 6 and Supplementary Table S5). The number of IS elements varied from 25 in strain ED23-35 to 39 in strain EK30A. Strains ED23-35 and ED45-23 contains 9 families of IS elements, three other permafrost strains harbored IS elements representing 11 families. Genomes of all environmental strains contain IS1, IS3, IS4, IS5, IS6, IS30, IS982, ISNCY families. The genome of strain ED9-5A contains IS21 and ISL3, which are absent in four other permafrost strains. The genome of $A$. lwoffii ZS207 additionally contains the IS21, IS200, IS481, IS701 and ISL3 families, and the genome of A. lwoffii M2a contains IS21, IS701 and IS1595. The genome of the strain M2a contains the largest number of different IS elements. In general, in terms of the number and diversity of IS elements, permafrost strains do not differ significantly from the other environmental strains. 
Table 6. Mobile elements in environmental strains of $A$. lwoffii.

\begin{tabular}{ccccccccc}
\hline Strain & ED23-35 & ED45-23 & ED9-5A & VS15 & EK30A & GC2 & ZS207 $^{\mathbf{1}}$ & M2a $^{\mathbf{1}}$ \\
\hline Total number of copies of IS elements & 78 & 70 & 107 & 98 & 133 & 25 & 86 & 205 \\
Number of IS elements & 25 & 29 & 34 & 33 & 39 & 23 & 40 & 49 \\
Number of families of IS elements & 9 & 9 & 11 & 11 & 11 & 10 & 15 & 13 \\
Composite transposons & 2 & 4 & 0 & 3 & 4 & 0 & 0 & 2 \\
Assembly quality (number & $\mathrm{C} / \mathrm{P}$ & $\mathrm{C} / \mathrm{P}$ & $\mathrm{C} / \mathrm{P}$ & $\mathrm{C} / \mathrm{P}$ & $\mathrm{C} / \mathrm{P}$ & 285 & $\mathrm{C} / \mathrm{P}$ & 277 \\
\hline $\begin{array}{l}\text { of scaffolds) } \\
\text { 2 }\end{array}$ & & & & & &
\end{tabular}

${ }^{1}$ data from reference $[32] ;{ }^{2} \mathrm{C} / \mathrm{P}$, complete chromosome and plasmids.

Most of the IS elements in the genomes of environmental strains are present in 1 to 10 copies per genome. The number of copies of ISAba11 of the IS701 family, found in the genomes of A. lwoffii ED23-35, VS15, EK30A, and M2a, ranges from 8 to 13; however, the genome of strain ZS207 contains only two copies of ISAba11, the genome of strain GC2 contains only one copy, and the strains ED45-23 and ED9-5A do not contain this IS element (Supplementary Table S5).

Analysis of the presence of IS elements in clinical strains of $A$. lwoffii was more complicated because all these genomes were assembled at the scaffold level (from 9 to 245). The actual copy number of IS elements could be underestimated due to collapsing of multiple identical IS copies into a single contig, that is particularly evident for the draft genome of strain TG19636. Nevertheless, both SH145 and NIPH 478 clinical strains were shown to contain the least variety of IS families (Table 7).

Table 7. Mobile elements in clinical strains of A. lwoffii.

\begin{tabular}{ccccccc}
\hline Strain & SH145 & NIPH 715 & CIP 70.31 & NIPH 478 & NIPH 512 & TG19636 \\
\hline Total number of copies of IS elements & 7 & 90 & 115 & 19 & 57 & 19 \\
Number of IS elements & 7 & 30 & 31 & 8 & 18 & 19 \\
Number of families of IS elements & 4 & 19 & 11 & 3 & 9 & 10 \\
Composite transposons & 0 & 0 & 0 & 0 & 0 & 0 \\
Assembly quality (number of scaffolds) & 76 & 26 & 12 & 9 & 12 & 245 \\
\hline
\end{tabular}

Analysis of genomes of environmental strains of A. lwoffii revealed the presence of several composite transposons, which are mobile genetic elements consisting of two IS elements flanking a DNA fragment often containing antibiotic resistance and other adaptive genes. Putative composite transposons were found in four out of five permafrost strains and in strain M2a but in none of the clinical isolate (Tables 6 and 7). Only one transposon, found in strain VS15, carried antibiotic resistance determinant, while most other harbored genes involved in various metabolic processes (Supplementary Table S6). Two of the composite transposons found in permafrost strains were also found in clinical A. lwoffii strains FDAARGOS 1393 and FDAARGOS_552 (Supplementary Table S6).

Earlier, based on the analysis of more than 200 bacterial genomes, it was shown that composite transposons, mostly containing antibiotic resistance genes, are most often found in clinical bacterial strains, usually on plasmids [62]. Wagner suggested that the preservation of spontaneously occurring composite transposons is stimulated by strong selective pressure in the clinic [62]. Therefore, the presence of a larger number of composite transposons in environmental $A$. lwoffii strains compared to clinical ones is unexpected.

\subsection{Plasmids}

Since the comparison of the complete genomes of $A$. lwoffii strains did not reveal significant differences between clinical and environmental, or modern and permafrost isolates, we decided to compare the plasmids of modern and permafrost strains. As mentioned above, the genomes of modern strains that we used for comparison, with the exception of ZS207, were not assembled at the level of complete chromosomes and 
plasmids. Therefore, we compared the frequency of occurrence of genes for resistance to heavy metals and antibiotics among permafrost and modern plasmids of $A$. lwoffii.

Among 41 permafrost plasmids, only three (7.3\%) harbored one antibiotic resistance gene, and seven plasmids (17.1\%) contained resistance genes to various heavy metals and arsenic (Supplementary Table S7). Among the 64 modern plasmids isolated from various sources, eight $(12.5 \%)$ contained from one to three antibiotic resistance genes and $11(17.2 \%)$ plasmid carrying genes for resistance to heavy metals and arsenic. Thus, it is obvious that modern plasmids are enriched with antibiotic resistance genes compared to permafrost ones, while the content of genes for resistance to heavy metals and arsenic in both samples are comparable. It should be noted that $A$. lwoffii strains, unlike $A$. baumanii, are part of the normal microbiota of the skin and mucous membranes of healthy people [63], so most strains isolated from human samples can hardly be considered pathogenic. However, modern strains of $A$. lwoffii, when exposed to antibiotics, begin to accumulate appropriate resistance genes, which is typical for clinical and veterinary samples. The accumulation of new adaptive genes occurs so far only on plasmids, and large plasmids ( $>40 \mathrm{~kb})$ play a major role in such adaptation.

\subsection{Integrated Phages}

To date, more than 100 bacteriophages infecting bacteria of the genus Acinetobacter have been described. They belong to the families Siphoviridae, Podoviridae, and Myoviridae [64]. As a result of the analysis of the genomes using the PHASTER program, 52 prophages integrated into the chromosome were found, of which 11 were presumably intact. The sizes of intact prophages ranged from 18.9 to $50.4 \mathrm{~kb}$ (Table 8).

Table 8. Intact prophages identified in the genomes of permafrost strains of A. lwoffii.

\begin{tabular}{cccccc}
\hline Strain & Phage & Length, (kb) & Position & Location & $\begin{array}{c}\text { Similar Prophages } \\
\text { (Coverage 1/Identity, \%) }\end{array}$ \\
\hline ED23-35 & ED23-35-3 & 34.1 & $1709101-1743234$ & Chromosome & - \\
& ED23-35-6 & 20 & $2260258-2280259$ & Chromosome & EK30A-7 (30/93.4) \\
\hline ED45-23 & ED45-23-1 & 33.6 & $1543115-1576799$ & Chromosome & - \\
\hline & ED45-23-4 & 43.7 & $2081979-2125746$ & Chromosome & - \\
& ED45-23-7 & 50.4 & $3208722-3259176$ & Chromosome & VS15-6 (45/91.4) \\
\hline ED9-5A & ED9-5A-1 & 37.8 & $994113-1031993$ & Chromosome & - \\
& ED9-5A-3 & 39 & $2063965-2103060$ & Chromosome & - \\
& ED9-5A-6 & 18.9 & $972-19932$ & pALWED 3.6 & ED23-35-6 (36/93.8) \\
\hline VS15 & VS15-6 & 49.6 & $2753607-2803257$ & Chromosome & ED45-23-7 (46/91.4) \\
\hline EK30A & EK30A-7 & 36.6 & $1504782-1541418$ & Chromosome & - \\
& EK30A-8 & 24.5 & $2890359-2914858$ & Chromosome & ED45-23-7 (55/94.3) \\
& & & & VS15-6 (38/95.5)
\end{tabular}

\footnotetext{
${ }^{1}$ Only similarities covering more than $30 \%$ of the prophage length.
}

Although no completely identical prophages were found in different permafrost strains, many prophages contained extended regions (up to $55 \%$ of their length), that had a high $(>90 \%)$ nucleotide sequence similarity to intact prophages of other strains (Table 8). Probably this is a result of active engagement of horizontal genetic exchange in evolution of Acinetobacter phages leading to formation of phage genomes mosaic in their architectures [65].

The sequences of 11 intact prophages from permafrost strains were compared with the genomes of $A$. lwoffii strains deposited in GenBank. For two prophages, similar sequences (more than $70 \%$ identity over $70 \%$ of the prophage length) were found in the genomes of various clinical strains of $A$. lwoffii. A region similar to ED45-23-1 prophage was found in the genome of the Acinetobacter johnsonii E10B (89\% identity over 85\% length) from prawn 
digestive tract. Near complete (99\% identity over $94 \%$ length) copy of EK30A-8 prophage was identified in the genome of clinical strain A. lwoffii FDAARGOS_551.

\subsection{Urea Utilization Operon and its Functional Activity in Permafrost Strains}

The presence of genetic determinants of urea utilization is one of the features that distinguish environmental strains of $A$. lwoffii from clinical isolates. The urease operon enabling the hydrolysis of urea into carbon dioxide and ammonia was identified in the genomes of all five permafrost strains of A. lwoffii, as well as in strains M2a and GC2, but was absent only in the genome environmental strain ZS207. On the contrary, of the six analysed clinical strains of $A$. lwoffii, only two contained the urease operon.

The operon includes the ure $A B C$ genes encoding the three subunits of urease and the auxiliary genes ureEFGD encoding the proteins required for the synthesis of the catalytically active Ni-containing form of the enzyme [66]. The product of another gene, ureJ, belongs to the pf04955 family of translocases and is likely to transport nickel into the cell [67].

The structures of urease operons in clinical and environmental strains of $A$. lwoffii are similar (Figure 2). In strains ED45-23 and EK30A, which have identical structures of the urease operon, the N-acetyltransferase gene (pfam13673) is inserted between the ureB and ure C genes. An operon with identical structure was found in the environmental strain M2a. In the clinical strain TG19636 there are two copies of the urease operon, one of which has the standard ure $A B C$ structure, and the second additionally contains the $\mathrm{N}$-acetyltransferase gene (Figure 2). Similar structure of urease operons (without the $\mathrm{N}$-acetyltransferase gene) was observed in A. bereziniae and A. guillouiae, while in other Acinetobacter species the order of genes is different (Figure 2).
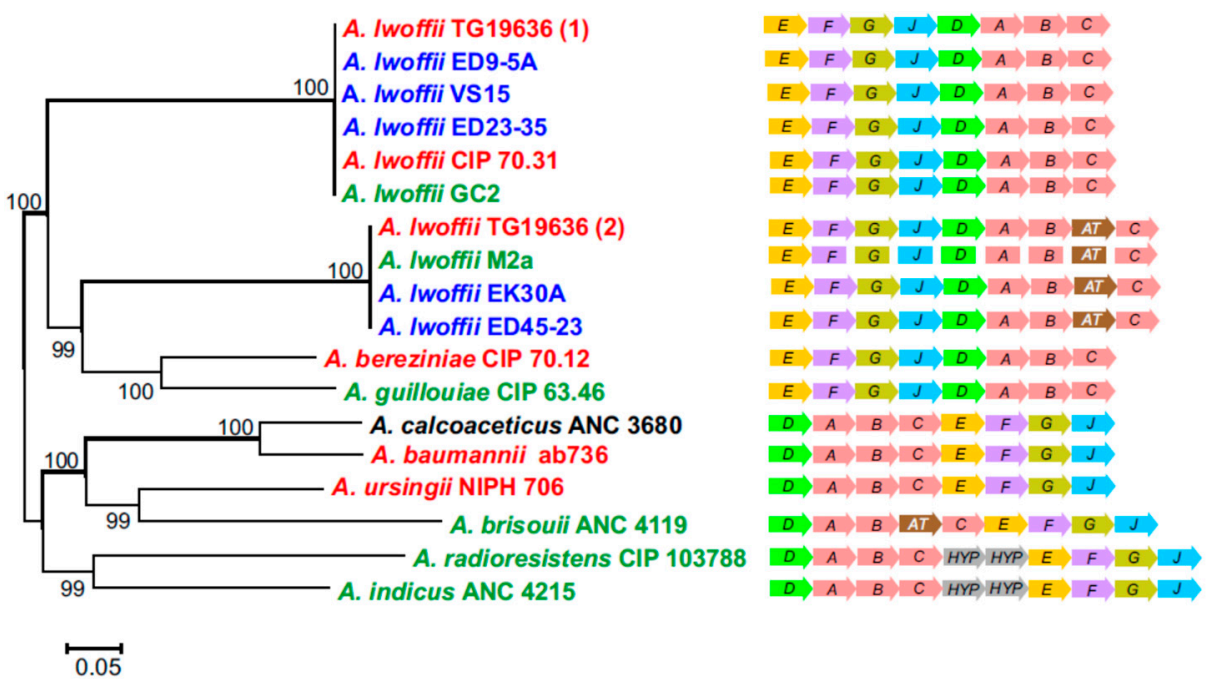

Figure 2. Structural organization and phylogeny of urease operon in Acinetobacter. The maximum likelihood phylogenetic tree was based on the concatenated amino acid sequences of eight proteins of the urease operon. Clinical, permafrost and other natural isolates of Acinetobacter are shown in red, blue and green, respectively. The origin of A. calcoaceticus AMC 3860 is unknown. AT, $\mathrm{N}$-acetyltransferase gene; HYP, genes encoding hypothetical proteins.

Phylogenetic analysis of concatenated amino acid sequences of proteins (UreA, UreB, UreC, UreD, UreE, UreF, UreG, and UreJ) of the urease operons revealed clustering of two structural types of the operons in A. lwoffii, rather than operons of environmental and clinical strains of this species (Figure 2).

In addition to the urease operon in the genomes of all analysed environmental and clinical strains, the urt $A B C D E$ operon, which encodes the urea $A B C$ transporter induced under nitrogen deficiency [68], was identified. In all these strains the urt operon is located on the chromosome. Urea imported into the cell can be cleaved either by urease or by a pair 
of enzymes, urea carboxylase and allophanate hydrolase. Genes encoding both enzymes are present in all analysed $A$. lwoffii strains.

The ability of the permafrost strains to utilize urea as a nitrogen source was determined by inoculation on Christensen's agar [50]. A change in the colour of the medium, reflecting a change in $\mathrm{pH}$ due to the hydrolysis of urea, was reliably detected only in the case of strain VS15 (Figure 3).

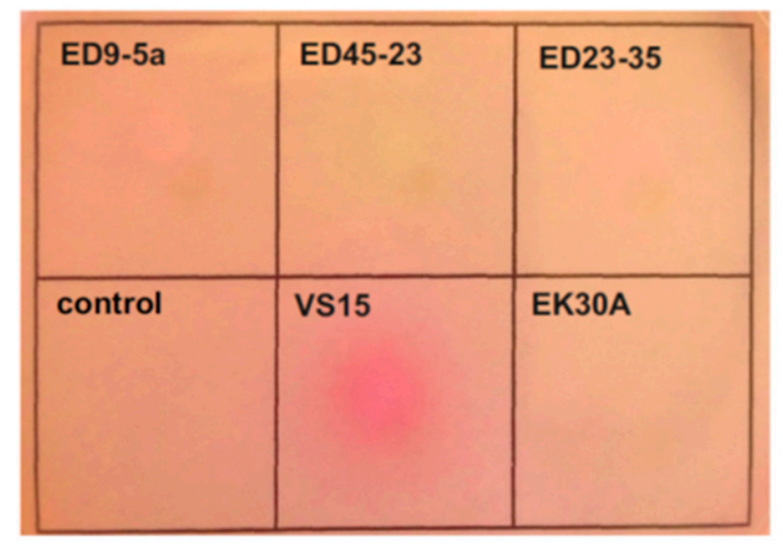

Figure 3. Evaluation of urase activity by Christensen's method. Cultures were dropped onto a Christensen Urea Agar plate and grown overnight. Christensen liquid medium was used as a negative control.

In A. lwoffii strains ED23-35 and VS15, the urease operon is localized on plasmids pALWED1.2 and pALWVS1.1, respectively, while in strains ED45-23, ED9-5A, and EK30A, this operon is located on the chromosome. In contrast to pALWED1.2, the copy number of which is about one per chromosome, the copy number of pALWVS1.1 is higher (about 3.6), which probably leads to higher urease activity due to the gene dose effect.

\section{Conclusions}

Analysis of genomes of five A. lwoffii strains isolated from permafrost aged from 15 thousand to 1.6 million years did not reveal genetic determinants that distinguish them from clinical $A$. lwoffii strains and strains from other non-clinical environments. Phylogenetic analysis based on whole genome sequences also showed that permafrost strains do not form a separate cluster, but are related to various clinical isolates. The genomes of clinical and permafrost strains contain similar mobile elements and prophages, which indicates an intense horizontal transfer of genetic material. However, comparison of plasmids of modern and permafrost strains showed that modern plasmids are enriched with antibiotic resistance genes, while the content of genes for resistance to heavy metals and arsenic is nearly the same. The thawing of permafrost caused by global warming could release new strains of Acinetobacter that could be potentially pathogenic to humans.

Supplementary Materials: The following are available online at https:/ / www.mdpi.com/article / 10.3390/biology10090871/s1, Table S1: Sequencing statistics, Table S2: Pairwise nucleotide sequence identity (\%) between the genomes of $A$. lwoffii strains, Table S3: List of genes present in all 8 environmental strains but missing in at least one of 6 clinical strains, Table S4: List of genes present in all 6 clinical strains but missing in at least one of 8 environmental strains, Table S5: Distribution of IS elements in the genomes of clinical and environmental strains of $A$. lwoffii, Table S6: Composite transposons in the genomes of $A$. lwoffii., Table S7: Resistance genes on plasmids and chromosomes of contemporary strains of $A$. lwoffii.

Author Contributions: Conceptualization, M.P., A.V.M. and N.V.R.; methodology, A.L.R., and A.Y.E.; validation, A.L.R. and A.V.B.; investigation, A.L.R., A.Y.E., A.V.B., M.P. and A.V.M.; resources, M.P.; data curation, A.V.B. and N.V.R.; writing—original draft preparation, A.L.R., M.P. and N.V.R.; writingreview and editing., N.V.R.; supervision, N.V.R.; project administration, N.V.R.; funding acquisition, A.V.M. and N.V.R. All authors have read and agreed to the published version of the manuscript. 
Funding: This research was funded by Ministry of Science and Higher Education of the Russian Federation under the agreement No. 075-15-2020-907 dated 16 November 2020 on the provision of a grant in the form of subsidies from the federal budget for the implementation of state support for the creation and development of a world-class scientific center "Agrotechnologies of the Future".

Institutional Review Board Statement: Not applicable.

Informed Consent Statement: Not applicable.

Data Availability Statement: All sequences associated with this work have been deposited at the National Center for Biotechnology Information under BioProject ID: PRJNA325719.

Acknowledgments: This work was performed using the scientific equipment of the Core Research Facility 'Bioengineering' (Research Center of Biotechnology RAS).

Conflicts of Interest: The authors declare no conflict of interest.

\section{References}

1. Jansson, J.K.; Taş, N. The microbial ecology of permafrost. Nat. Rev. Microbiol. 2014, 12, 414-425. [CrossRef]

2. Porfiriev, B.N.; Eliseev, D.O.; Streletskiy, D.A. Economic Assessment of Permafrost Degradation Effects on Road Infrastructure Sustainability under Climate Change in the Russian Arctic. Her. Russ. Acad. Sci. 2019, 89, 567-576. [CrossRef]

3. Steven, B.; Léveillé, R.; Pollard, W.H.; Whyte, L.G. Microbial ecology and biodiversity in permafrost. Extremophiles 2006, 10, 259-267. [CrossRef]

4. Zhang, D.C.; Brouchkov, A.; Griva, G.; Schinner, F.; Margesin, R. Isolation and characterization of bacteria from ancient siberian permafrost sediment. Biology 2013, 2, 85-106. [CrossRef]

5. Steven, B.; Briggs, G.; McKay, C.P.; Pollard, W.H.; Greer, C.W.; Whyte, L.G. Characterization of the microbial diversity in a permafrost sample from the Canadian high Arctic using culture-dependent and culture-independent methods. FEMS Microbiol. Ecol. 2007, 59, 513-523. [CrossRef]

6. Vishnivetskaya, T.A.; Petrova, M.A.; Urbance, J.; Ponder, M.; Moyer, C.L.; Gilichinsky, D.A.; Tiedje, J.M. Bacterial community in ancient Siberian permafrost as characterized by culture and culture-independent methods. Astrobiology 2006, 6, 400-414. [CrossRef]

7. Gilichinsky, D.A.; Vorobyova, E.A.; Erokhina, L.G.; Fyordorov-Davydov, D.G.; Chaikovskaya, N.R. Long-term preservation of microbial ecosystems in permafrost. Adv. Space Res. 1992, 12, 255-263. [CrossRef]

8. Kashuba, E.; Dmitriev, A.A.; Kamal, S.M.; Melefors, O.; Griva, G.; Römling, U.; Ernberg, I.; Kashuba, V.; Brouchkov, A. Ancient permafrost staphylococci carry antibiotic resistance genes. Microb. Ecol. Health Dis. 2017, 28, 1345574. [CrossRef]

9. Berendonk, T.U.; Manaia, C.M.; Fatta-kassinos, D.; Cytryn, E.; Walsh, F.; Bürgmann, H.; Sørum, H.; Norström, M.; Pons, M.-N.; Kreuzinger, N.; et al. Tackling antibiotic resistance: The environmental framework. Nat. Rev. Microbiol. $2015,13,310-317$. [CrossRef]

10. Davies, J.; Davies, D. Origins and evolution of antibiotic resistance. Microbiol. Mol. Biol. Rev. 2010, 74, 417-433. [CrossRef] [PubMed]

11. Allen, H.K.; Donato, J.; Wang, H.H.; Cloud-Hansen, K.A.; Davies, J.; Handelsman, J. Call of the wild: Antibiotic resistance genes in natural environments. Nat. Rev. Microbiol. 2010, 8, 251-259. [CrossRef]

12. Perry, J.; Waglechner, N.; Wright, G. The prehistory of antibiotic resistance. Cold Spring Harb. Perspect. Med. 2016, 6, a025197. [CrossRef]

13. Petrova, M.; Gorlenko, Z.; Mindlin, S. Molecular structure and translocation of a multiple antibiotic resistance region of a Psychrobacter psychrophilus permafrost strain. FEMS Microbiol. Lett. 2009, 296, 190-197. [CrossRef]

14. Petrova, M.; Gorlenko, Z.; Mindlin, S. Tn5045, a novel integron-containing antibiotic and chromate resistance transposon isolated from a permafrost bacterium. Res. Microbiol. 2011, 162, 337-345. [CrossRef]

15. D'Costa, V.M.; King, C.E.; Kalan, L.; Morar, M.; Sung, W.W.L.; Schwarz, C.; Froese, D.; Zazula, G.; Calmels, F.; Debruyne, R.; et al. Antibiotic resistance is ancient. Nature 2011, 477, 457-461. [CrossRef]

16. Kurakov, A.; Mindlin, S.; Beletsky, A.; Shcherbatova, N.; Rakitin, A.; Ermakova, A.; Mardanov, A.; Petrova, M. The ancient small mobilizable plasmid pALWED1.8 harboring a new variant of the non-cassette streptomycin/spectinomycin resistance gene aadA27. Plasmid 2016, 84-85, 36-43. [CrossRef] [PubMed]

17. Perron, G.; Whyte, L.; Turnbaugh, P.; Hanage, W.P.; Dantas, G.; Desai, M.M. Functional characterization of bacteria isolated from ancient arctic soil exposes diverse resistance mechanisms to modern antibiotics. PLoS ONE 2015, 10, e0069533.

18. Afouda, P.; Dubourg, G.; Levasseur, A.; Fournier, P.E.; Delerce, J.; Mediannikov, O.; Diene, S.M.; Nahon, D.; Bourlès, D.; Rolain, J.M.; et al. Culturing Ancient Bacteria Carrying Resistance Genes from Permafrost and Comparative Genomics with Modern Isolates. Microorganisms 2020, 8, 1522. [CrossRef] [PubMed]

19. Mindlin, S.; Minakhin, L.; Petrova, M.; Kholodii, G.; Minakhina, S.; Gorlenko, Z.; Nikiforov, V. Present-day mercury resistance transposons are common in bacteria preserved in permafrost grounds since the Upper Pleistocene. Res. Microbiol. 2005, 156, 994-1004. [CrossRef] 
20. Mindlin, S.; Petrenko, A.; Kurakov, A.; Beletsky, A.; Mardanov, A.; Petrova, M. Resistance of Permafrost and Modern Acinetobacter lwoffii Strains to Heavy Metals and Arsenic Revealed by Genome Analysis. BioMed. Res. Int. 2016, 2016, 3970831. [CrossRef]

21. Jung, J.; Park, W. Acinetobacter species as model microorganisms in environmental microbiology: Current state and perspectives. Appl. Microbiol. Biotechnol. 2015, 99, 2533-2548. [CrossRef] [PubMed]

22. Hongsawat, P.; Vangnai, A.S. Biodegradation pathways of chloroanilines by Acinetobacter baylyi strain GFJ2. J. Hazard. Mater. 2011, 186, 1300-1307. [CrossRef] [PubMed]

23. Vaneechoutte, M.; Young, D.M.; Ornston, L.N.; De Baere, T.; Nemec, A.; Van Der Reijden, T.; Carr, E.; Tjernberg, I.; Dijkshoorn, L. Naturally transformable Acinetobacter sp. strain ADP1 belongs to the newly described species Acinetobacter baylyi. Appl. Environ. Microbiol. 2006, 72, 932-936. [CrossRef]

24. Doughari, H.J.; Ndakidemi, P.A.; Human, I.S.; Benade, S. The Ecology, Biology and Pathogenesis of Acinetobacter spp.: An Overview. Microbes Environ. 2011, 26, 101-112. [CrossRef]

25. Ku, S.C.; Hsueh, P.R.; Yang, P.C.; Luh, K.T. Clinical and microbiological characteristics of bacteremia caused by Acinetobacter lwoffii. Eur. J. Clin. Microbiol. Infect. Dis. 2000, 19, 501-505. [CrossRef]

26. Regalado, N.; Martin, G.; Antony, S. Acinetobacter lwoffii: Bacteremia associated with acute gastroenteritis. Travel Med. Infect. Dis. 2009, 7, 316-317. [CrossRef]

27. Turton, J.; Shah, J.; Ozongwu, C.; Pike, R. Incidence of Acinetobacter species other than A. baumannii among clinical isolates of Acinetobacter: Evidence for emerging species. J. Clin. Microbiol. 2010, 48, 1445-1449. [CrossRef]

28. Partridge, S.R.; Kwong, S.M.; Firth, N.; Jensen, S.O. Mobile Genetic Elements Associated with Antimicrobial Resistance. Clin. Microbiol. Rev. 2018, 31, e00088-17. [CrossRef]

29. Cerezales, M.; Xanthopoulou, K.; Wille, J.; Krut, O.; Seifert, H.; Gallego, L.; Higgins, P.G. Mobile Genetic Elements Harboring Antibiotic Resistance Determinants in Acinetobacter baumannii Isolates From Bolivia. Front. Microbiol. 2020, 11, 919. [CrossRef]

30. López, M.; Rueda, A.; Florido, J.P.; Blasco, L.; Fernández-García, L.; Trastoy, R.; Fernández-Cuenca, F.; Martínez-Martínez, L.; Vila, J.; Pascual, A.; et al. Evolution of the Quorum network and the mobilome (plasmids and bacteriophages) in clinical strains of Acinetobacter baumannii during a decade. Sci. Rep. 2018, 8, 2523. [CrossRef]

31. Walter, T.; Klim, J.; Jurkowski, M.; Gawor, J.; Köhling, I.; Słodownik, M.; Zielenkiewicz, U. Plasmidome of an environmental Acinetobacter lwoffii strain originating from a former gold and arsenic mine. Plasmid 2020, 110, 102505. [CrossRef]

32. Veress, A.; Nagy, T.; Wilk, T.; Kömüves, J.; Olasz, F.; Kiss, J. Abundance of mobile genetic elements in an Acinetobacter lwoffii strain isolated from Transylvanian honey sample. Sci. Rep. 2020, 10, 2969. [CrossRef] [PubMed]

33. Acer, Ö.; Güven, K.; Poli, A.; Di Donato, P.; Leone, L.; Buono, L.; Güven, R.G.; Nicolaus, B.; Finore, I. Acinetobacter mesopotamicus sp. nov., petroleum-degrading bacterium, isolated from petroleum-contaminated soil in Diyarbakir, in the southeast of Turkey. Curr. Microbiol. 2020, 77, 3192-3200. [CrossRef]

34. Nemec, A. Strain "Acinetobacter mesopotamicus" GC2 Does Not Represent a Novel Species, but Belongs to the Species Acinetobacter lwoffii as Revealed by Whole-Genome Sequence-Based Analysis. Curr. Microbiol. 2021, 78, 369-370. [CrossRef] [PubMed]

35. Mindlin, S.Z.; Petrova, M.A.; Gorlenko, Z.M.; Soina, V.S.; Khachikian, N.A.; Karaevskaya, E.A. Multidrug-resistant bacteria in permafrost: Isolation, biodiversity, phenotypic and genotypic analysis. In New Permafrost and Glacier Research, 1st ed.; Krugger, M.I., Stern, H.P., Eds.; Nova Science: Hauppauge, NY, USA, 2009; pp. 89-105.

36. Martin, M. Cutadapt removes adapter sequences from highthroughput sequencing reads. EMBnet J. 2011, 17, 10-12. [CrossRef]

37. Magoč, T.; Salzberg, S.L. FLASH: Fast length adjustment of short reads to improve genome assemblies. Bioinformatics 2011, 27, 2957-2963. [CrossRef] [PubMed]

38. Wick, R.R.; Judd, L.M.; Gorrie, C.L.; Holt, K.E. Unicycler: Resolving bacterialgenome assemblies from short and long sequencing reads. PLoS Comput. Biol. 2017, 13, e1005595. [CrossRef]

39. Brettin, T.; Davis, J.J.; Disz, T.; Edwards, R.A.; Gerdes, S.; Olsen, G.J.; Olson, R.; Overbeek, R.; Parrello, B.; Pusch, G.D.; et al. RASTtk: A modular and extensible implementation of the RAST algorithm for building custom annotation pipelines and annotating batches of genomes. Sci. Rep. 2015, 5, 8365. [CrossRef]

40. Korf, I.; Gish, W. MPBLAST: Improved BLAST performance with multiplexed queries. Bioinformatics 2000, 16, 1052-1053. [CrossRef] [PubMed]

41. Katoh, K.; Misawa, K.; Kuma, K.; Miyata, T. MAFFT: A novel method for rapid multiple sequence alignment based on fast Fourier transform. Nucleic Acids Res. 2002, 30, 3059-3066. [CrossRef] [PubMed]

42. Talavera, G.; Castresana, J. Improvement of phylogenies after removing divergent and ambiguously aligned blocks from protein sequence alignments. Syst. Biol. 2007, 56, 564-577. [CrossRef]

43. Guindon, S.; Delsuc, F.; Dufayard, J.F.; Gascuel, O. Estimating maximum likelihood phylogenies with PhyML. Methods Mol. Biol. 2009, 537, 113-137.

44. Rodriguez, R.L.M.; Konstantinidis, K.T. The enveomics collection: A toolbox for specialized analyses of microbial genomes and metagenomes. PeerJ Prepr. 2016, 4, e1900v1.

45. McArthur, A.G.; Waglechner, N.; Nizam, F.; Yan, A.; Azad, M.A.; Baylay, A.J.; Bhullar, K.; Canova, M.J.; De Pascale, G.; Ejim, L.; et al. The comprehensive antibiotic resistance database. Antimicrob. Agents Chemother. 2013, 57, 3348-3357. [CrossRef] [PubMed]

46. Siguier, P.; Perochon, J.; Lestrade, L.; Mahillon, J.; Chandler, M. ISfinder: The reference centre for bacterial insertion sequences. Nucleic Acids Res. 2006, 34, D32-D36. [CrossRef] [PubMed] 
47. Arndt, D.; Grant, J.R.; Marcu, A.; Sajed, T.; Pon, A.; Liang, Y.; Wishart, D.S. PHASTER: A better, faster version of the PHAST phage search tool. Nucleic Acids Res. 2016, 44, W16-W21. [CrossRef] [PubMed]

48. Edgar, R.C. MUSCLE: Multiple sequence alignment with high accuracy and high throughput. Nucleic Acids Res. 2004, 32, 1792-1797. [CrossRef]

49. Tamura, K.; Stecher, G.; Peterson, D.; Filipski, A.; Kumar, S. MEGA6: Molecular Evolutionary Genetics Analysis version 6.0. Mol. Biol. Evol. 2013, 30, 2725-2729. [CrossRef]

50. Christensen, W.B. Urea decomposition as a means of differentiating Proteus and paracolon cultures from each other and from Salmonella and Shigella types. J. Bacteriol. 1946, 52, 461-466. [CrossRef]

51. Konstantinidis, K.T.; Tiedje, J.M. Genomic insights that advance the species definition for prokaryotes. Proc. Natl. Acad. Sci. USA 2005, 102, 2567-2572. [CrossRef]

52. Jain, C.; Rodriguez, R.L.M.; Phillippy, A.M.; Konstantinidis, K.T.; Aluru, S. High throughput ANI analysis of 90K prokaryotic genomes reveals clear species boundaries. Nat. Commun. 2018, 9, 5114. [CrossRef] [PubMed]

53. Weinitschke, S.; Denger, K.; Cook, A.M.; Smits, T.H.M. The DUF81 protein TauE in Cupriavidus necator H16, a sulfite exporter in the metabolism of C2 sulfonates. Microbiology 2007, 153, 3055-3060. [CrossRef] [PubMed]

54. Cook, A.M.; Denger, K. Dissimilation of the C2 sulfonates. Arch. Microbiol. 2002, 179, 1-6. [CrossRef] [PubMed]

55. Chen, I.; Dubnau, D. DNA uptake during bacterial transformation. Nat. Rev. Microbiol. 2004, 2, 241-249. [CrossRef]

56. Domingues, S.; Rosário, N.; Cândido, Â.; Neto, D.; Nielsen, K.M.; Da Silva, G.J. Competence for Natural Transformation Is Common among Clinical Strains of Resistant Acinetobacter spp. Microorganisms 2019, 7, 30. [CrossRef] [PubMed]

57. Williams, C.L.; Neu, H.M.; Alamneh, Y.A.; Reddinger, R.M.; Jacobs, A.C.; Singh, S.; Abu-Taleb, R.; Michel, S.L.J.; Zurawski, D.V.; Merrell, D.S. Characterization of Acinetobacter baumannii copper resistance reveals a role in virulence. Front. Microbiol. 2020, 11, 16. [CrossRef]

58. Figueiredo, S.; Poirel, L.; Seifert, H.; Mugnier, P.; Benhamou, D.; Nordmann, P. OXA-134, a naturally occurring carbapenemhydrolyzing class D beta-lactamase from Acinetobacter lwoffii. Antimicrob. Agents Chemother. 2010, 54, 5372-5375. [CrossRef]

59. Ermakova, A.Y.; Beletsky, A.V.; Mardanov, A.V.; Petrova, M.A.; Ravin, N.V.; Rakitin, A.L. A Novel Plasmid pALWVS1.4 from Acinetobacter lwoffii Strain VS15, Carrying the Chloramphenicol Resistance Gene. Microbiology 2020, 89, 637-640. [CrossRef]

60. Siguier, P.; Gourbeyre, E.; Varani, A.; Ton-Hoang, B.; Chandler, M. Everyman's Guide to Bacterial Insertion Sequences. Microbiol. Spectr. 2015, 3, MDNA3-0030-2014. [CrossRef]

61. Siguier, P.; Gourbeyre, E.; Chandler, M. Bacterial insertion sequences: Their genomic impact and diversity. FEMS Microbiol. Rev. 2014, 38, 865-891. [CrossRef]

62. Wagner, A. Cooperation is fleeting in the world of transposable elements. PLoS Comput. Biol. 2006, 2, e162. [CrossRef] [PubMed]

63. Seifert, H.; Dijkshoorn, L.; Gerner-Smidt, P.; Pelzer, N.; Tjernberg, I.; Vaneechoutte, M. Distribution of Acinetobacter species on human skin: Comparison of phenotypic and genotypic identification methods. J. Clin. Microbiol. 1997, 35, 2819-2825. [CrossRef] [PubMed]

64. Turner, D.; Ackermann, H.W.; Kropinski, A.M.; Lavigne, R.; Sutton, J.M.; Reynolds, D.M. Comparative Analysis of 37 Acinetobacter Bacteriophages. Viruses 2017, 10, 5. [CrossRef]

65. Hatfull, G.F.; Hendrix, R.W. Bacteriophages and their genomes. Curr. Opin. Virol. 2011, 1, 298-303. [CrossRef]

66. Mobley, H.L.; Island, M.D.; Hausinger, R.P. Molecular biology of microbial ureases. Microbiol. Rev. 1995, 59, 451-480. [CrossRef] [PubMed]

67. Eitinger, T.; Suhr, J.; Moore, L.; Smith, J.A. Secondary transporters for nickel and cobalt ions: Theme and variations. Biometals 2005, 18, 399-405. [CrossRef]

68. Beckers, G.; Bendt, A.K.; Krämer, R.; Burkovski, A. Molecular identification of the urea uptake system and transcriptional analysis of urea transporter-and urease-encoding genes in Corynebacterium glutamicum. J. Bacteriol. 2004, 186, 7645-7652. [CrossRef] [PubMed] 